\title{
18. NEOGENE LOW-LATITUDE MAGNETOSTRATIGRAPHY FROM SITE 710 AND REVISED AGE ESTIMATES OF MIOCENE NANNOFOSSIL DATUM EVENTS ${ }^{1}$
}

\author{
Jan Backman, ${ }^{2}$ David A. Schneider, ${ }^{3}$ Domenico Rio, ${ }^{4}$ and Hisatake Okada ${ }^{5}$
}

\begin{abstract}
Ocean Drilling Program Leg 115 recovered, for the first time, a largely continuous Neogene magnetostratigraphic sequence from an equatorial environment. This sequence (Site 710) has been correlated to the geomagnetic polarity time scale by means of nannofossil biostratigraphy. When the Miocene nannofossil magnetobiochronology from Site 710 is compared with other predominantly mid-latitude magnetobiochronologies, an evaluation of consistency can be made. The results require substantial revision of the age estimates of Miocene nannofossil zonal markers, relative to the values presented in the currently accepted Neogene nannofossil chronology.
\end{abstract}

\section{INTRODUCTION}

The geomagnetic polarity time scale (GPTS) from marine magnetic anomaly patterns forms a basic element in most attempts to develop a Cenozoic geochronology. To establish a reliable chronology for deep-sea sediment sequences, it is necessary to combine biostratigraphic and magnetostratigraphic data within the framework of a single time scale. The degree of accuracy depends largely on the proper identification of the magnetostratigraphic reversal sequence. Uncertainties arise partly from the difficulty of retrieving complete magnetostratigraphic sequences that represent long periods of time. Moreover, the precise sequencing of biostratigraphic species events, within and between species groups, remains open to refinement. But once adequate magnetostratigraphic sequences are established, we should be able to transform precise biostratigraphic information into an accurate biochronology.

Despite the fact that much effort has been made in establishing high quality magnetostratigraphic records from deep-sea sediments, no continuous Miocene record from a low-latitude environment currently exists. The results obtained from Ocean Drilling Program (ODP) Leg 115, however, approach such a record and may help arrange several essential pieces of the Miocene biochronology puzzle. The purpose of this paper is (1) to present a recently cored Miocene magnetostratigraphic record from the equatorial Indian Ocean; (2) to present the biostratigraphy of selected calcareous nannofossil marker fossils from that Miocene sequence; and (3) to discuss the revisions to the Miocene nannofossil biochronology given by Berggren et al. (1985), a recent compilation that represents a wealth of data on marine biostratigraphy, magnetostratigraphy, and radiochronology and that has been widely adopted by marine geologists.

These revisions are proposed largely on the basis of our results from Site 710, but we also use observations from several other key deep-sea sediment sections.

\section{GEOLOGICAL SETTING}

Leg 115 drilled two holes at Site 710, which is located on the Madingley Rise in the western equatorial Indian Ocean $\left(04^{\circ} 18.7^{\prime} \mathrm{S}\right.$,

\footnotetext{
${ }^{1}$ Duncan, R. A., Backman, J., Peterson, L. C., et al., 1990. Proc. ODP, Sci. Results, 115: College Station, TX (Ocean Drilling Program).

2 Department of Geology, University of Stockholm, S-105 91 Stockholm, Sweden.

${ }^{3}$ Lamont-Doherty Geological Observatory, Palisades, New York 10964, U.S.A.

${ }^{4}$ Department of Geology, University of Padova, I-35137 Padova, Italy.

${ }^{5}$ Department of Earth Sciences, Yamagata University, Yamagata, 990 Japan.
}

$60^{\circ} 58.8^{\prime} \mathrm{E}$ ) at a water depth of $3824.3 \mathrm{~m}$. The 100 -m-thick Miocene section shows strongly varying carbonate content, with the largest variability in the early and middle Miocene (Backman, Duncan, et al., 1988). The Miocene carbonate fraction of the sediment is largely composed of calcareous nannofossils, this site having been below the foraminifer lysocline throughout most of the Miocene. The Miocene deposition pattern was not uncomplicated, and many signs of sedimentological disturbance are present in the cores. The disturbed sections (in Cores 115$710 \mathrm{~A}-8 \mathrm{H}$ and $-10 \mathrm{H}$ ) are omitted from the following discussion.

\section{MAGNETOSTRATIGRAPHY}

The magnetic polarity stratigraphy of Site 710 (Schneider and Kent, this volume) is determined from two types of paleomagnetic data: from near-continuous records obtained with the shipboard cryogenic pass-through magnetometer system, and from at least one discrete sample from each $1.5-\mathrm{m}$ core section. The low paleomagnetic inclination in these near-equatorial sediments is typically obscured by noise (Schneider and Kent, this volume) and cannot, in general, be used to determine magnetic polarity. Instead, we relied on $180^{\circ}$ shifts in declination to identify the reversal boundaries within each core. Thus, we were able to derive a magnetostratigraphy only from cores obtained by hydraulic piston coring (i.e., without rotary drilling). Because attempts to orient these cores in azimuth failed, the measured declinations do not indicate the sense of reversal.

Polarity sense in each core, however, can be established from either an analysis of discrete samples (which often retain a reasonable recording of the primary inclination) or of those portions of the pass-through magnetometer record that clearly show inclination changes at reversal boundaries. Despite the potential uncertainty in this approach, we judged that the polarity sense could be determined reliably. Along with our interpretation of the polarity stratigraphy, we show declinations determined from pass-through measurements and from discrete samples. Note that in presenting the paleomagnetic data, we have rotated each core's azimuth so as to bring the mean declination of the presumed normal polarity zones to $0^{\circ}$.

We have not made a polarity interpretation at the top of Core 115-710A-8H, where reworking is extensive; in Core 115$710 \mathrm{~A}-10 \mathrm{H}$, where slumping may have overturned bedding; and also at the bottom of Core 115-710A-11H and top of Core 115$710 \mathrm{~A}-12 \mathrm{H}$, where the declinations are confused. Furthermore, the polarity zonation shown does not include many apparent short polarity intervals seen in the pass-through magnetometer record. We have also excluded one thin normal polarity interval within the Gilbert Chron that is associated with a turbidite 
layer. This zone is somewhat ill-defined in the paleomagnetic record and cannot be reasonably correlated to the GPTS.

\section{CORRELATION OF SITE 710 RECORD TO THE GPTS}

To examine Miocene nannofossil biochronology, we must establish the proper correlation between the magnetostratigraphy of Site 710 and the GPTS. Figure 1 shows the magnetic polarity record obtained from Site 710 , together with the stratigraphic positions of selected calcareous nannofossil markers.

\section{Pleistocene-Pliocene}

The Pleistocene reversal sequence is readily identified despite a recoring problem and some incompleteness. In the early Pliocene, the two best calibrated nannofossil markers are the last occurrence (LO) of Reticulofenestra pseudoumbilica, associated with the latest Gilbert Chron, and the first occurrence (FO) of Ceratolithus rugosus, associated with the later part of the Thvera Subchron (Backman and Shackleton, 1983). These events were recognized at $29.9 \pm 0.2 \mathrm{~m}$ below seafloor (mbsf) and $39.55 \pm$ 0.05 mbsf, respectively, in Hole 710B, thus identifying the youngest Gilbert Chron as well as the normal Thvera Subchron. Apart from displaying the Thvera clearly, Core $115-710 \mathrm{~B}-5 \mathrm{H}$ also contains a large portion of the oldest Gilbert reversed interval, in which the FO of Ceratolithus acutus (41.75 \pm 0.45 mbsf), and the LOs of Triquetrorhabdulus rugosus $(42.4 \pm 0.2$ mbsf) and Discoaster quinqueramus ( $43.4 \pm 0.3 \mathrm{mbsf})$ occur.

\section{Late Miocene}

Amaurolithus primus is the next older marker species that aids the identification of the magnetic polarity record. Its FO is thought to occur in the older part of Chron C3A (Berggren et al., 1985). At Site 710 , this event occurs at $60.55 \pm 0.25 \mathrm{mbsf}$ in both holes, indicating that the normal polarity intervals in Cores $115-710 \mathrm{~A}-6 \mathrm{H}$ and $115-710 \mathrm{~B}-6 \mathrm{H}$ belong to Chron C3A. The FO of $D$. quinqueramus occurs at the very base of Core $115-710 \mathrm{~A}-7 \mathrm{H}$, immediately below the two uppermost magnetic normal intervals interpreted as representing Chron $\mathrm{C} 4$. Core $115-710 \mathrm{~A}-9 \mathrm{H}$ contains three well-established markers that occur in their proper stratigraphic order: the LO of Discoaster hamatus $(78.7 \pm 0.3 \mathrm{mbsf})$, the LO of Catinaster spp. (79.2 \pm 0.2 mbsf), and the FO of Discoaster neohamatus (80.2 $\pm 0.3 \mathrm{mbs}$ ). Miller et al. (1985) calibrated the first two of these events to basal Chron $\mathrm{C} 4 \mathrm{~A}$, implying that the long interval of normal polarity in Core $115-710 \mathrm{~A}-9 \mathrm{H}$ represents Chron C5. This core also contains the lowermost observed specimens of $D$. hamatus at 84.8 mbsf, immediately below the base of Chron C $5 \mathrm{~N}$. However, the true FO level is probably obscured by slumping.

\section{Middle and Early Miocene}

Unfortunately, Core 115-710A-10H displays several slumps; therefore, we did not attempt to interpret the magnetic polarity record there. Nevertheless, this core contains the following middle Miocene nannofossil marker events: the FOs of Catinaster coalitus, Discoaster kugleri, and Triquetrorhabdulus rugosus, and the LOs of Cyclicargolithus floridanus and Sphenolithus heteromorphus.

Because we cannot connect the magnetic reversal sequence in Core 115-710A-10H reliably to the GPTS, we are forced to find a new control point somewhere within Cores $115-710 \mathrm{~A}-11 \mathrm{H}$, $-12 \mathrm{H}$, or $-13 \mathrm{H}$ that can be confidently correlated to the GPTS. Biostratigraphy reveals that these sediments were deposited during early middle through late early Miocene time: $S$. heteromorphus is present down through most of Core $115-710 \mathrm{~A}-12 \mathrm{H}$, Sphenolithus belemnos occurs in the core catcher of Core 115$710 \mathrm{~A}-12 \mathrm{H}$, and Triquetrorhabdulus carinatus is present throughout Core $115-710 \mathrm{~A}-13 \mathrm{H}$.
The biostratigraphic information contained in Cores 115 . $710 \mathrm{~A}-14 \mathrm{H}$ and $-15 \mathrm{H}$ (which lack magnetostratigraphy) also constrain the interpretation of the magnetic polarity record in Cores $115-710 \mathrm{~A}-11 \mathrm{H}$ through $-13 \mathrm{H}$. The FO of Discoaster druggii occurs at 132.4 mbsf. The bottom of Core $115-710 \mathrm{~A}-13 \mathrm{H}$ is thus located about $7.5 \mathrm{~m}$ above the FO of D. druggii (which Berggren et al., 1985, associated with Chron C6B). Furthermore, the bottom part of Core $115-710 \mathrm{~A}-12 \mathrm{H}$ is likely older than Chron C5DN because the FO of $S$. heteromorphus is calibrated with the magnetostratigraphic event that occurs below this normal interval (Miller et al., 1985). Bracketed by these constraints, and taking into account the relative durations (in the GPTS) and lengths (in $115-710 \mathrm{~A}-13 \mathrm{H}$ ) of the early Miocene polarity sequence, we conclude that the long normal polarity interval in Core $115-710 \mathrm{~A}-13 \mathrm{H}$ represents Chron C6N. The shorter normals below Chron $\mathrm{C} 6 \mathrm{~N}$ presumably represent Chrons $\mathrm{C} 6 \mathrm{~A}$ and C6AA.

Considering the FO level of $S$. heteromorphus at $114.2 \pm$ $0.2 \mathrm{mbsf}$ in Core 115-710A-12H, it appears justified to suggest that the normal polarity interval (top at $114.7 \mathrm{mbsf}$ ) at the very base of Core 115-710A-12 H represents Chron C5E, and that the remaining two normal polarity intervals in this core represent Chrons C5D and C5C. Again, by matching the pattern of the GPTS with the polarity zones in Hole $710 \mathrm{~A}$, and taking into account the age/depth constraints presented above, the most reasonable interpretation of the two rather long normal polarity intervals in Core $115-710 \mathrm{~A}-11 \mathrm{H}$ is that they represent Chrons C5 AD and C5AC.

\section{REVISED MIOCENE NANNOFOSSIL BIOCHRONOLOGY}

Although the Neogene magnetostratigraphy of Site 710 is of variable quality, it is still one of the best low-latitude records available. A comparison of the nannofossil biochronology obtained at Site 710 with other data sets from different latitudes and ocean basins would suggest revisions to many age estimates of important datum events. The implications of these results, compared with the Neogene nannofossil biochronology presented by Berggren et al. (1985), are summarized in Figure 2.

A few points in the zonal systems of Martini (1971; NP/NN zones), and Okada and Bukry (1980; CP/CN zones) need to be clarified. When Bukry $(1973,1975)$ defined zonal boundaries, he commonly used two species events for a given boundary. The age of such zonal boundaries may vary considerably, depending on which of the two events is used (see Bukry, 1978; Berggren et al., 1985, table 7). Zone CN3 seems to have lost its significance: it is defined by the FOs of S. heteromorphus (bottom) and Calcidiscus macintyrei (top) (Bukry, 1975, 1978), and the latter species has since been found to appear stratigraphically below the former species (e.g., Haq and Takayama, 1984; Knüttel, 1986; Olafsson, 1989). Bukry (1973) originally used the LO of Helicosphaera ampliaperta for definition of the $\mathrm{CN} 3 / \mathrm{CN} 4$ boundary. If that concept is retained, Zone $\mathrm{CN} 3$ would be meaningful again and therefore we adopt this latter definition.

Martini (1971) defined the NP25/NN1 boundary by the LO of Helicosphaera recta. This species has a nearly simultaneous extinction with $S$. ciperoensis at nearby Site 714 (Backman, Duncan, et al., 1988), and we have used the latter species for definition of the NP25/NN1 boundary (this is the only case where we do not adhere to original zonal boundary definitions). Berggren et al. (1985) used the LO of Dictyococcites bisectus for the NP25/NN1 and the CP19/CN1 boundaries. This is the only case where Berggren et al. (1985) use one of Bukry's two possible zonal boundary definitions, and we use the other (S. ciperoensis). We have not tried to apply Bukry's (1973, 1975) acme concepts because these have never been defined quantitatively. Finally, when considering sample intervals and sedimentation 
Hole 710A

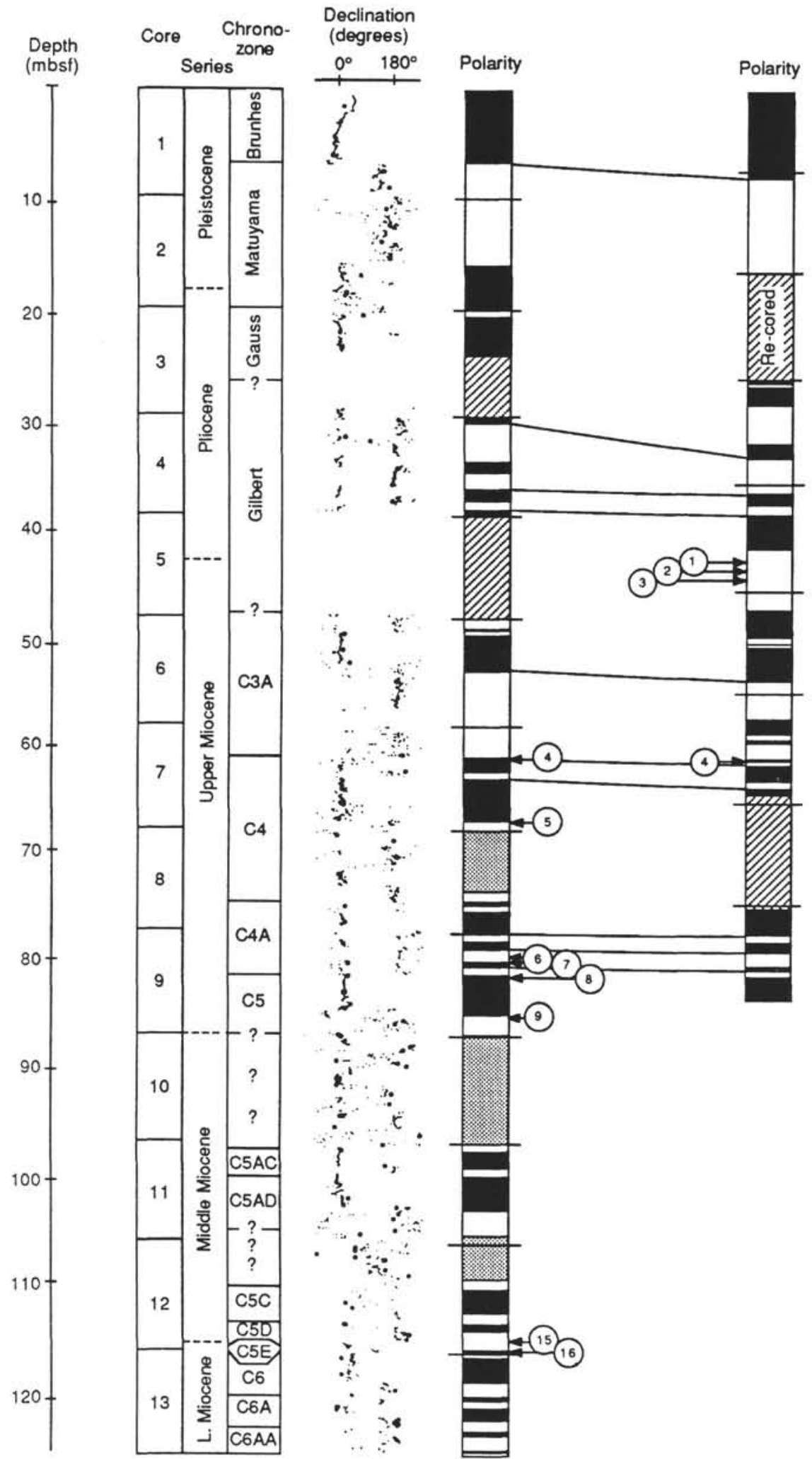

Hole $710 \mathrm{~B}$

Declination (degrees) Chrono- Core

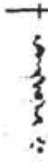

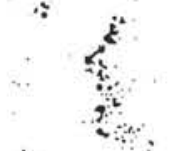<smiles>[14CH3]</smiles>
.

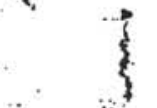

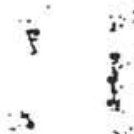

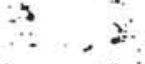$$
\rightarrow \text { in }
$$

i<smiles>[Te][Te]</smiles><smiles>[C]1[C+]=CC=C1</smiles><smiles>[C]1CCCC1</smiles><smiles>[TeH]</smiles>

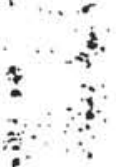

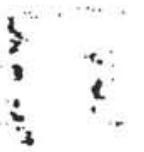

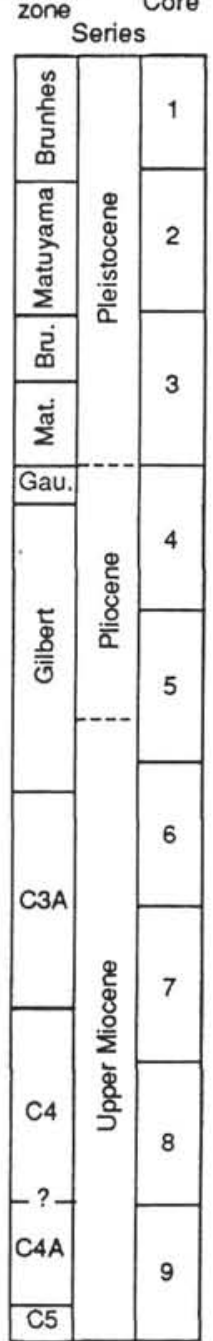

Figure 1. Magnetostratigraphy of Site 710. Lines of correlation between the two holes are shown. Numbers beside polarity records represent the nannofossil marker events listed in Table 1. Declination measurements are from pass-through magnetometer measurements after 5-mT demagnetization (small dots) and from progressive AG demagnetization of discrete samples (larger dots). Declinations of each core have been rotated (see text). Normal polarity zones are shown as black; reverse polarity, as white. Shaded areas indicate sections not interpreted for polarity. Hatchure lines show levels of no recovery. Epoch boundaries (shown dashed), based on nannofossils, are approximate. 


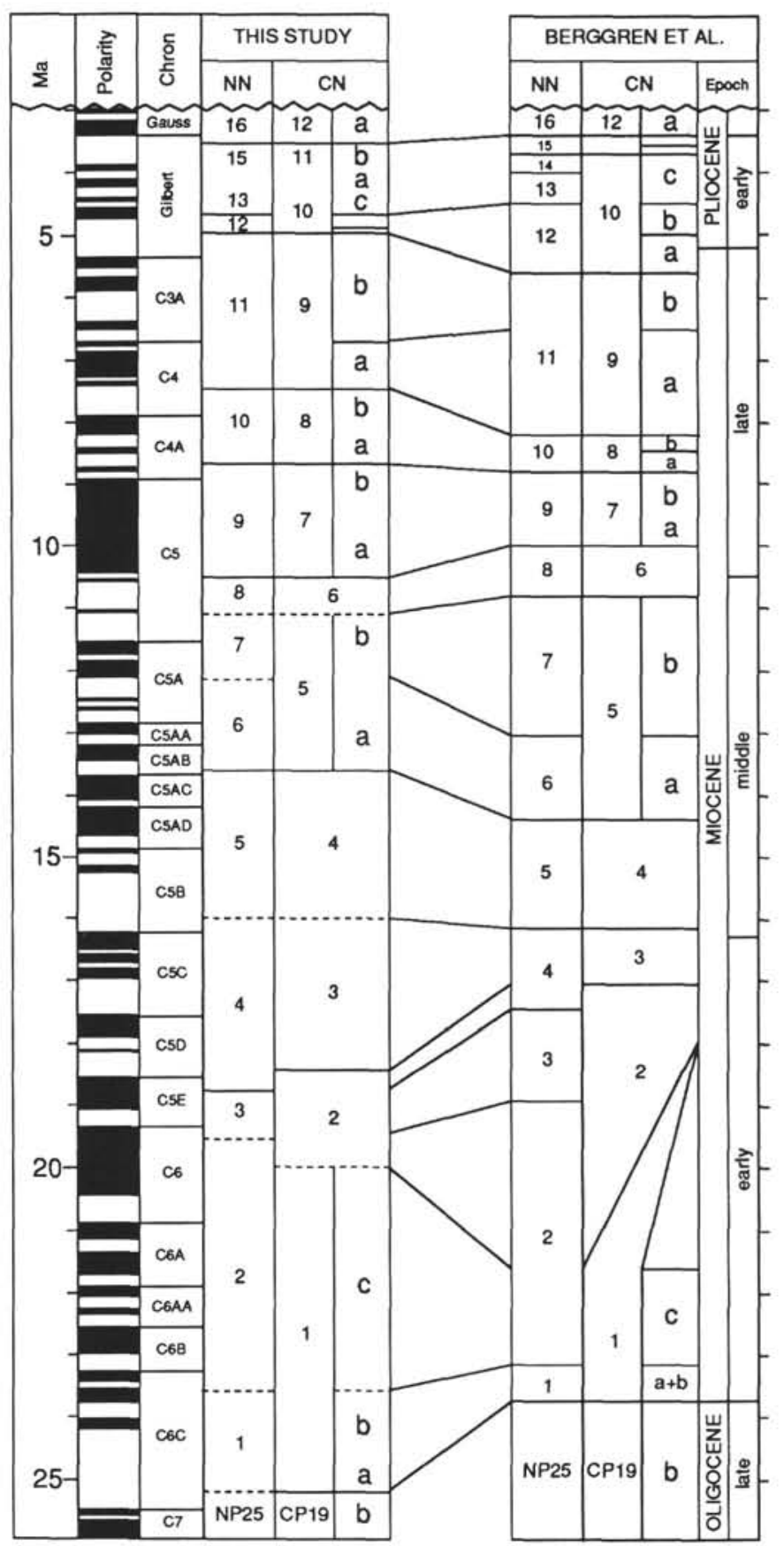

Figure 2. Correlation of early Pliocene through latest Oligocene nannofossil zonal boundaries (Martini, 1971, NN/NP; Okada and Bukry, $1980, \mathrm{CN} / \mathrm{CP}$ ) to GPTS of Berggren et al. (1985). Both our correlations and those of Berggren et al. (1985) are shown. Dashed line at CN3/4 boundary implies the use of the LO of $\mathrm{H}$. ampliaperta rather than the FO of C. macintyrei for definition. Hatchured line at NP25/NN1 boundary implies the use of the LO of $S$. ciperoensis rather than the LO of $H$. recta for definition. Berggren et al. (1985) used $D$. bisectus for their definition of both NP25/NN1 and CP19/CN1 boundaries. Remaining dashed lines at zonal boundaries represent age estimates not directly correlated to magnetostratigraphy. rates, this suggests that the resolution of the age estimates presented below is, in general, better than $0.1 \mathrm{~m} . \mathrm{y}$.

\section{Earliest Pliocene and Late Miocene}

The sedimentation rate calculated from the Thvera boundaries can be extrapolated downward to derive age estimates for $C$. acutus (FO), T. rugosus (LO), and $D$. quinqueramus (LO) without crossing a core boundary. This yields age estimates of 4.85 , 4.90 , and $4.98 \mathrm{Ma}$, respectively. The LO of $D$. quinqueramus is assigned an age that is $0.6 \mathrm{~m}$.y. younger at Site 710 than the estimate of Berggren et al. (1985). Their estimate was based on results from a condensed, severely dissolved piston core (RC1266 ) and on the magnetostratigraphically poorly constrained Deep Sea Drilling Project (DSDP) Site 397. Our age estimate of 4.98 $\mathrm{Ma}$ for the $D$. quinqueramus extinction is in excellent agreement with results from DSDP Site 577 (4.98 Ma; Monechi, 1985; Bleil, 1985; see also Gartner et al., 1984; Muza et al., 1987).

Our estimate of the $A$. primus FO differs only slightly from that of Berggren et al. (1985); 6.64 (Hole 710B) to $6.72 \mathrm{Ma}$ (Hole $710 \mathrm{~A}$ ) vs. $6.5 \mathrm{Ma}$, whereas our estimate of the $D$. quinqueramus $\mathrm{FO}$ is considerably younger (7.46 Ma in Hole $710 \mathrm{~A}$ vs. 8.2 Ma). Results from Site 711 also yield an age of 7.41-7.50 Ma for this event (Backman, Duncan, et al., 1988). Berggren et al. (1985) used data in Haq et al. (1980) and Miller et al. (1985) for estimating the age of $D$. quinqueramus. Haq et al. (1980) referred this datum event to upper Epoch 8 (7.41-7.90 Ma) in Core RC12-418, whereas Miller et al. (1985) showed a questionable FO of $D$. quinqueramus at the very top of Site 563. Parker et al. (1985) and Bukry (1985), however, did not observe this species in Site 563, but Parker et al. (1985) observed the FOs of both $A$. primus and $D$. quinqueramus from DSDP Hole 558A. There, the two events are separated by one core that is predominantly of normal polarity direction, events which Kahn et al. (1985) did not attempt to correlate to the GPTS. The weight of this evidence points to an age estimate of the FO of $D$. quinqueramus in the range from 7.41 to $7.50 \mathrm{Ma}$.

Our magnetostratigraphic record from Site 710 shows a nearperfect match of the lower Chron C4A/upper Chron C5 interval to the chronology of Berggren et al. (1985). Thus, we consider our age estimate of $8.67 \mathrm{Ma}$ for the LO of $D$. hamatus as reliable. The ages for the LO of Catinaster spp. and the FO of $D$. neohamatus, as derived from Hole $710 \mathrm{~A}$, are 8.77 and $8.96 \mathrm{Ma}$, respectively. The lowermost observed $D$. hamatus has been assigned an age of about $10.5 \mathrm{Ma}$, which should be regarded with caution because of the complicated biostratigraphy in basal Core 115-710A-9H. Available data, however, still point to a lowlatitude age estimate at least $0.5 \mathrm{~m}$.y. older than the mid-latitude estimate (10.0 Ma) of Berggren et al. (1985).

\section{Middle Miocene}

Data from Site 710 indicate clearly that the extinction of $S$. heteromorphus (top CN4/NN5) occurred after 13.69 Ma. Moreover, a similar result is obtained from DSDP Site 608 in the midlatitude North Atlantic, which probably represents one of the clearest available middle Miocene magnetostratigraphic records (Clement and Robinson, 1987). With Takayama and Sato's data (1987), an age of $13.6 \mathrm{Ma}$ was calculated for the NN5/6 boundary. By assuming a constant sedimentation rate between the NN8/9 (10.5 Ma) and NN5/6 (13.6 Ma) boundaries in Hole $714 \mathrm{~A}$, the NN6/7 (FO D. kugleri and the NN7/8 boundaries (FO C. coalitus) yield age estimates of 12.2 and $11.1 \mathrm{Ma}$, respectively. An age of 13.1 Ma has been calculated for the LO of C. floridanus from DSDP Site 574 .

The LO of $H$. ampliaperta (CN3/4 or NN4/5 boundary) is not present in Site 710, although the pertinent stratigraphic interval was recovered. Its final occurrence in Site 608 yields a 
slightly younger age (15.89-16.12 Ma; Baldauf et al., 1987) than the estimate of 16.2 Ma proposed by Berggren et al. (1985).

\section{Early Miocene}

The FO of $S$. heteromorphus (CN2/3 boundary) is located in the reversed interval lying above what we take to reflect Chron C5E at Site 710 and has been assigned an age of $18.30 \mathrm{Ma}$. Enhanced dissolution of the carbonate fraction in the later half of the early Miocene at Site 710 has, however, resulted in condensation and markedly low sedimentation rates. In Site 608, this species appears in exactly the same magnetostratigraphic position (basal Chron C5D; Clement and Robinson, 1987; Takayama and Sato, 1987) as at Site 710. But because the critical interval in Site 608 has a 4.5 times higher sedimentation rate than that at Site 710, we prefer the estimate derived from Site 608 $(18.42 \mathrm{Ma})$. The duration of the total range of $S$. heteromorphus has thus increased from the previous estimate of 2.7 m.y. (Berggren et al., 1985) to $4.8 \mathrm{~m} . \mathrm{y}$.

The LO of $S$. belemnos (NN3/4 boundary) occurs slightly below the FO of $S$. heteromorphus in Hole 710A, with an estimated age of $18.79 \mathrm{Ma}$. At Site 608, Baldauf et al. (1987) estimated an age of $18.74 \mathrm{Ma}$ for the NN3/4 boundary. In both cases this boundary is associated with a normal polarity interval, presumably reflecting Chron C5E. The FO of $S$. belemnos represents the only major ambiguity we experience in our correlation of the Miocene nannofossil biostratigraphy to the GPTS. This species was observed only in the core catcher of Core 115$710 \mathrm{~A}-12 \mathrm{H}$, and we presume that we have lost some sediment across the Core $115-710 \mathrm{~A}-12 \mathrm{H} / 13 \mathrm{H}$ boundary. Alternatively, the strong dissolution characterizing the upper part of Chron C6N in Core 115-710A-13H may have confused our understanding of the true range of $S$. belemnos. Thus, we cannot directly calibrate the FO of $S$. belemnos to magnetostratigraphy in any of the Leg 115 sites.

Highly inconsistent age estimates of the FO of $S$. belemnos, ranging from 20.7 to 22.5 Ma (Sites 558 and 563; Parker et al., 1985; Bukry, 1985; Kahn et al., 1985; Miller et al., 1985), or 20.2 Ma (Site 608; Clement and Robinson, 1987; Takayama and Sato, 1987), are obtained when other magnetostratigraphic records are considered, . If we assume constant sedimentation rates from Site 667 in the equatorial Atlantic Ocean (Olafsson, 1989) and Site 714 in the equatorial Indian Ocean (Backman, Duncan, et al., 1988), however, and use the CP19/CN1 (25.2 $\mathrm{Ma}$; see below) and $\mathrm{CN} 2 / 3(18.42 \mathrm{Ma})$ boundaries as control points, a consistent age estimate of $20.0 \mathrm{Ma}$ is obtained for the FO of $S$. belemnos.

Thus, the stratigraphic range of $S$. belemnos in equatorial regions suggests a duration of $1.2 \mathrm{~m} . \mathrm{y}$. $(18.8-20.0 \mathrm{Ma})$, which is nearly 3.5 times shorter than the 4.1-m.y. mid-latitude estimate of Berggren et al. (1985; 17.4-21.5 Ma). This large difference in the duration of $S$. belemnos hardly stems from a mid-latitude ecological preference, but rather emphasizes the fact that we still, by and large, lack unambiguous biomagnetostratigraphic reference sections from this time interval. Undoubtedly, there will be cause for returning to this particular problem when such sections become available.

Berggren et al. (1985) suggested that the LO of $T$. carinatus, which many consider an unreliable datum (e.g., Parker et al., 1985; Olafsson, 1989), occurs close to the base of Chron C5EN (at 19.0 Ma). We propose a slightly older age (19.5 Ma) for this event, because it appears to fall approximately midway between the FO of $S$. heteromorphus and S. belemnos. This age estimate is supported by results from DSDP Site 574 (19.3 Ma; Pujos, 1985; Olafsson, 1989).

The FO of $D$. druggii (NN1/2 or $\mathrm{CN} 1 \mathrm{~b} / \mathrm{CN} 1 \mathrm{c}$ boundary) apparently falls below Chron C6AA at Site 710, and hence below our magnetostratigraphic record. To derive an age estimate for this event from the equatorial Indian Ocean, we have used a constant sedimentation rate between the onset of C6AAN2 (124.70 mbsf; $22.35 \mathrm{Ma})$ and the LO of $S$. ciperoensis $(142.25$ mbsf; $25.2 \mathrm{Ma}$ ). This results in an age of $23.6 \mathrm{Ma}$ (suggesting uppermost C6C), which is close to the Berggren et al. (1985) estimate of $23.2 \mathrm{Ma}$ (lowermost C6B).

The LO of S. ciperoensis is identified at Site 711 (Backman, Duncan, et al., 1988), immediately above the zone we associate with Chron $\mathrm{C} 7$, in agreement with the age estimate $(25.2 \mathrm{Ma})$ of Berggren et al. (1985).

\section{CONCLUSIONS}

Our version of Miocene nannofossil biochronology (Table 1 and Fig. 2) deviates in many respects from the time scale of Berggren et al. (1985). When they proposed their biochronology, they had access to only mid-latitude biomagnetostratigraphic records, whereas our version is determined mainly from the first reasonably continuous magnetostratigraphic record available from a Miocene low-latitude, open-ocean environment. Comparison of our nannofossil biochronology with newly recovered mid-latitude data seems, in most cases, to yield consistent age estimates. Although we consider that our version represents improved correlations between Miocene nannofossil biostratigraphy and the GPTS of Berggren et al. (1985), we do not consider this to be the definitive scheme with global applicability. Without a doubt, this revised biochronology will be further altered when better magnetostratigraphic sequences are recovered (particularly those events that still lack direct correlation to magnetostratigraphy from low-latitude environments). Nevertheless, our Miocene nannofossil biochronology implies that existing correlations between planktonic foraminifer and nannofossil zones must also need revision.

\section{ACKNOWLEDGMENTS}

Discussions with D. Kent and K. Miller resulted in an improved manuscript. We also acknowledge the constructive criti-

Table 1. Revised age estimates of Miocene nannofossil datums.

\begin{tabular}{|c|c|c|c|c|}
\hline Event $^{a}$ & Species & $\begin{array}{l}\text { Age } \\
(\mathrm{Ma})\end{array}$ & Site & $\begin{array}{l}\text { Zone } \\
\text { (top) }\end{array}$ \\
\hline $1 \mathrm{FO}$ & C. acutus & 4.85 & 710 & CN10a \\
\hline $2 \mathrm{LO}$ & T. rugosus & 4.90 & 710 & CN10a \\
\hline $3 \mathrm{LO}$ & D. quinqueramus & 4.98 & 710 & NN11/CN9b \\
\hline $4 \mathrm{FO}$ & A. primus & 6.70 & 710 & CN9a \\
\hline $5 \mathrm{FO}$ & D. quinqueramus & 7.46 & 710 & NN10 \\
\hline $6 \mathrm{LO}$ & D. hamatus & 8.67 & 710 & NN9/CN7b \\
\hline $7 \mathrm{LO}$ & Catinaster spp. & 8.77 & 710 & - \\
\hline $8 \mathrm{FO}$ & D. neohamatus & 8.96 & 710 & - \\
\hline $9 \mathrm{FO}$ & D. hamatus & 10.5 & 710 & NN8/CN6 \\
\hline $10 \mathrm{FO}$ & C. coalitus & ${ }^{b} 11.1$ & 714 & $\mathrm{NN} 7 / \mathrm{CN} 5 \mathrm{~b}$ \\
\hline $11 \mathrm{FO}$ & D. kugleri & $b_{12.2}$ & 714 & NN6/CN5a \\
\hline $12 \mathrm{LO}$ & C. floridanus & $c_{13.1}$ & 574 & CN5a \\
\hline $13 \mathrm{LO}$ & $S$. heteromorphus & 13.6 & 608 & NN5/CN4 \\
\hline $14 \mathrm{LO}$ & H. ampliaperta & 16.0 & 608 & $\mathrm{NN} 4 / \mathrm{CN} 3$ \\
\hline $15 \mathrm{FO}$ & S. heteromorphus & 18.4 & 608 & $\mathrm{CN} 2$ \\
\hline $16 \mathrm{LO}$ & S. belemnos & 18.8 & 710 & NN3 \\
\hline $17 \mathrm{LO}$ & T. carinatus & $\mathrm{d}_{19.5}$ & $714 / 715$ & NN2 \\
\hline $18 \mathrm{FO}$ & S. belemnos & ${ }^{e} 20.0$ & $667 / 714$ & CN1c \\
\hline $19 \mathrm{FO}$ & D. druggii & $f_{23.6}$ & 710 & $\mathrm{NN} 1 / \mathrm{CN} 1 \mathrm{~b}$ \\
\hline $20 \mathrm{LO}$ & S. ciperoensis & 25.2 & 711 & CP19b \\
\hline
\end{tabular}

Note: $\mathrm{FO}=$ first occurrence and $\mathrm{LO}=$ last occurrence.

a Nannofossil zonation of Martini $(1971 ; \mathrm{NN})$ and Okada and Bukry (1980; CP, CN).

${ }^{b}$ Linear interpolation between datums 9 and 13 .

c Linear extrapolation from datums 13 and 15.

d Linear interpolation between datums 15 and 18 .

e Linear interpolation between datums 15 and 20 .

${ }^{f}$ Linear interpolation between base of C6AAN2 and datum 20. 
cism provided by B. Clement, L. Tauxe, and S. W. Wise, Jr. Lamont-Doherty Geological Observatory Contribution No. 4577.

\section{REFERENCES}

Backman, J., Duncan, R. A., et al., 1988. Proc. ODP, Init. Repts., 115: College Station, TX (Ocean Drilling Program).

Backman, J., and Shackleton, N. J., 1983. Quantitative biochronology of Pliocene and early Pleistocene calcareous nannofossils from the Atlantic, Pacific and Indian oceans: Mar. Micropaleontol., 8:141170.

Baldauf, J. G., Thomas, E., Clement, B., Takayama, T., Weaver, P.P.E., Backman, J., Jenkins, G., Mudie, P. J., and Westberg-Smith, M. J., 1987. Magnetostratigraphic and biostratigraphic synthesis, Deep Sea Drilling Project Leg 94. In Ruddiman, W. F., Kidd, R. B., Thomas, E., et al., Init. Repts. DSDP, 94, Pt. 2: Washington (U.S. Govt. Printing Office), 1159-1205.

Berggren, W. A., Kent, D. V., and Van Couvering, J. A., 1985. The Neogene: Part 2, Neogene geochronology and chronostratigraphy. In Snelling, N. J. (Ed.), The Chronology of the Geological Record. Mem. Geol. Soc. (London): 10:211-260.

Bleil, U., 1985. The magnetostratigraphy of northwest Pacific sediments, Deep Sea Drilling Project Leg 86. In Heath, G. R., Burckle, L. H., et al., Init. Repts. DSDP, 86: Washington (U.S. Govt. Printing Office), 441-458.

Bukry, D., 1973. Low-latitude coccolith biostratigraphic zonation. In Edgar, N. T., Saunders, J. B., et al., Init. Repts. DSDP, 15: Washington (U. S. Govt. Printing Office), 685-704.

1975. Coccolith and silicoflagellate stratigraphy, northwestern Pacific Ocean, Deep Sea Drilling Project, Leg 32. In Larson, R. L., Moberly, R., et al., Init. Repts. DSDP, 32: Washington (U. S. Govt. Printing Office), 677-701.

1978. Biostratigraphy of Cenozoic marine sediments by calcareous nannofossils. Micropaleontology, 24:44-60.

, 1985. Mid-Atlantic Ridge coccolith and silicoflagellate biostratigraphy, Deep Sea Drilling Project Sites 558 and 563. In Bougault, H., Cande, S. C., et al., Init. Repts. DSDP, 82: Washington (U.S. Govt. Printing Office), 591-603.

Clement, B. M., and Robinson, F., 1987. The magnetostratigraphy of Leg 94 sediments. In Ruddiman, W. F., Kidd, R. B., Thomas, E., et al., Init. Repts. DSDP, 94, Pt. 2: Washington (U.S. Govt. Printing Office), $635-650$.

Gartner, S., Chen, M. P., and Stanton, R. J., 1984. Late Neogene nannofossil biostratigraphy and paleoceanography of the northeastern Gulf of Mexico and adjacent areas. Mar. Micropaleontol., 8:17-50.

Haq, B. U., and Takayama, T., 1984. Neogene calcareous nannoplankton datum planes and their correlation to magnetostratigraphy. In Ikebe, N., and Tsuchi, R. (Eds.), Pacific Neogene Datum Planes: Tokyo (Univ. Tokyo Press), 27-33.

Haq, B. U., Worsley, T. R., Burckle, L. H., Douglas, R. G., Keigwin, L. D., Opdyke, N. D., Savin, S. M., Sommer, M. A., Vincent, E., and Woodruff, F., 1980. Late Miocene carbon-isotopic shift and synchroneity of some phytoplanktonic biostratigraphic events. Geology, 8:427-431.
Khan, M. J., Kent, D. V., and Miller, K. G., 1985. Magnetostratigraphy of Oligocene to Pleistocene sediments, Sites 558 and 563. In Bougault, H., Cande, S. C., et al., Init. Repts. DSDP, 82: Washington (U. S. Govt. Printing Office), 385-392.

Knüttel, S., 1986. Calcareous nannofossil biostratigraphy of the central East Pacific Rise, Deep Sea Drilling Project Leg 92: evidence for downslope transport of sediments. In Leinen, M., Rea, D. K., et al., Init. Repts. DSDP, 92: Washington (U.S. Govt. Printing Office), 255-290.

Martini, E., 1971. Standard Tertiary and Quaternary calcareous nannoplankton zonation. In Farinacci, A. (Ed.), Proceedings of the Second International Conference on Planktonic Microfossils, Roma: Rome (Tecnoscienza), 2:739-785.

Miller, K. G., Aubry, M.-P., Khan, M. J., Melillo, A. J., Kent, D. V., and Berggren, W. A., 1985. Oligocene-Miocene biostratigraphy, magnetostratigraphy, and isotopic stratigraphy of the western North Atlantic. Geology, 13:257-261.

Monechi, S., 1985. Campanian to Pleistocene calcareous nannofossil stratigraphy from the northwest Pacific Ocean, Deep Sea Drilling Project Leg 86. In Heath, G. R., Burckle, L. J., et al., Init. Repts. DSDP, 86: Washington (U.S. Govt. Printing Office), 301-336.

Muza, J. P., Wise, S. W., Jr., and Mitchener Covington, J., 1987. Neogene calcareous nannofossils from Deep Sea Drilling Project Site 603, Lower Continental Rise, western North Atlantic: biostratigraphy and correlations with magnetic and seismic stratigraphy. In van Hinte, J. E., Wise, S. W., Jr., et al., Init. Repts. DSDP, 93, Pt. 2: Washington (U. S. Govt. Printing Office), 593-616.

Okada, H., and Bukry, D., 1980. Supplementary modification and introduction of code numbers to the low-latitude coccolith biostratigraphic zonation (Bukry, 1973; 1975). Mar. Micropaleontol., 5:321325.

Olafsson, G., 1989. Quantitative calcareous nannofossil biostratigraphy of upper Oligocene to middle Miocene sediment from ODP Hole 667A and middle Miocene sediment from DSDP Site 574. In Ruddiman, W., Sarnthein, M., et al., Proc. ODP, Sci. Results, 108: College Station, TX (Ocean Drilling Program), 9-22.

Parker, M. E., Clark, M., and Wise, S. W., Jr., 1985. Calcareous nannofossils of Deep Sea Drilling Project Sites 558 and 563, North Atlantic Ocean: biostratigraphy and the distribution of Oligocene braarudosphaerids. In Bougault, H., Cande, S. C., et al., Init. Repts. DSDP, 82: Washington (U.S. Govt. Printing Office), 559-589.

Pujos, A., 1985. Cenozoic nannofossils, central equatorial Pacific, Deep Sea Drilling Project Leg 85. In Mayer, L., Theyer, F., Thomas, E., et al., Init. Repts. DSDP, 85: Washington (U.S. Govt. Printing Office), 581-607.

Takayama, T., and Sato, T., 1987. Coccolith biostratigraphy of the North Atlantic Ocean, Deep Sea Drilling Project Leg 94. In Ruddiman, W. F., Kidd, R. B., Thomas, E., et al., Init. Repts. DSDP, 94 , Pt. 2: Washington (U.S. Govt. Printing Office), 651-702.

Date of initial receipt: 23 August 1989

Date of acceptance: 8 January 1990

Ms 115B-209 